\title{
Aspirin Impairs Transport of Protective Osmolytes in Renal Inner Medullary Collecting Duct Cells
}

\author{
Jeffrey S. Bonner, Bailey M. Anderson, Joshua Blevins and Stephen A. Kempson* \\ Department of Cellular \& Integrative Physiology, Indiana University School of Medicine, Indianapolis, IN 46202-5120, \\ USA
}

\begin{abstract}
Non-steroidal anti-inflammatory drugs (NSAIDs) represent one of the most common classes of medications used worldwide for treatment of pain and inflammation, and their nephrotoxic effects have been well documented. This study is focused on aspirin action on the normal adaptive responses of cells in the hypertonic renal inner medulla, using a cultured cell model. Following adaptation to hypertonic conditions, further treatment of both MDCK and $\mathrm{IMCD}_{3}$ cells for $24 \mathrm{~h}$ with $1.0 \mathrm{mM}$ aspirin produced significant inhibition of the transport systems for the osmolytes betaine and taurine. Caspase 3 was not activated by this treatment, indicating that transport inhibition was not due to apoptotic events. Acetaminophen and caffeine, common in analgesic mixtures, had a similar inhibitory effect. We conclude that interference with osmolyte accumulation by medullary cells may help to explain in part the nephrotoxicity due to long-term use of NSAIDs and analgesic formulations.
\end{abstract}

Keywords: Salicylic acid, acetaminophen, caffeine, caspase 3, kidney medulla, osmolyte.

\section{INTRODUCTION}

Non-steroidal anti-inflammatory drugs (NSAIDs), such as aspirin and ibuprofen, are used worldwide as analgesics and antipyretics, and an estimated 6-7 billion \$US is spent on them each year [1]. They are especially effective for treating inflammatory diseases (e.g. arthritis) through non-specific inhibition of cyclooxygenase (COX) enzymes which limits production of prostaglandins. The COX1 isoform appears to serve a constitutive housekeeping role, responsible for maintaining basic physiological functions, including cytoprotection of the gastric mucosa and control of platelet aggregation. In contrast, COX2 is induced by inflammatory mediators and mitogens and appears to play a key role in pathophysiological processes such as inflammation $[2,3]$. In the kidney, COX1 is highly expressed in the collecting duct, and low levels of COX1 are detected in interstitial cells, glomerular mesangial cells, and endothelial cells of arterioles. In contrast, COX2 is expressed predominantly in the renal medullary interstitial cells and in cortical thick ascending limb cells $[4,5]$. The expression of COX2 in these cells also can be induced after a variety of physiological stresses, such as salt-loading and hypertonicity $[2,5]$. One role may be to produce $\mathrm{PGE}_{2}$ during urinary concentration to regulate transport of water, salt and urea in collecting ducts. $\mathrm{PGE}_{2}$ also may improve survival of medullary cells during hypertonic stress [4]. Important side-effects of long-term NSAID therapy include injury to the gastrointestinal tract and papillary necrosis in the kidney. Selective COX2 inhibitors (e.g. vioxx, celecoxib) appear to cause similar problems [1]. NSAIDs may have direct effects on renal epithelial cells that express COX activity [6,7], and also may drive proliferation and apoptosis through effects unrelated to COX inhibition $[8,9]$.

\footnotetext{
*Address correspondence to this author at the Medical Sciences 306, 635 Barnhill Drive, Indianapolis, IN 46202-5120, USA; Tel: 317-274-1444; Fax: 317-274-3318; E-mail: skempson@iupui.edu
}

We are investigating if renal medullary injury by NSAIDs may be due in part to depletion of $\mathrm{PGE}_{2}$ and subsequent failure of the adaptive responses to the hypertonic inner medulla. Accumulation of osmolytes is important for cell survival in a hypertonic environment $[10,11]$, and atrophy of medullary tissue occurs when osmoprotective genes are not activated $[12,13]$. The present study is focused on the action of aspirin on the transport of specific osmolytes, betaine and taurine, in renal medullary cells. Acetaminophen and caffeine, non-NSAIDS, were included in the study because of reports that heavy consumption of the former can contribute to renal failure. In addition, coformulations of aspirin and acetaminophen are popular in many cold and allergy preparations because the dose of each can be reduced. Caffeine is often added to these analgesic mixtures because it can increase efficacy by $50 \%[14,15]$.

\section{METHODS AND MATERIALS}

Madin-Darby canine kidney (MDCK) and inner medullary collecting duct $\left(\mathrm{IMCD}_{3)}\right.$ cell lines, derived from the renal medulla of dog and mouse kidney respectively [16-18], were obtained from the American Type Culture Collection (Rockville, MD) and grown in monolayers in 24-well plates under standard culture conditions, as described in detail in our previous studies $[19,20]$. The growth medium was DMEM/F12 (1:1) containing 10\% bovine calf serum, $15 \mathrm{mM}$ Hepes, $25 \mathrm{mM} \mathrm{NaHCO} 3(\mathrm{pH} 7.4), 100 \mathrm{IU} / \mathrm{ml}$ penicillin and $100 \mu \mathrm{g} / \mathrm{ml}$ streptomycin. Hypertonic growth medium was made by addition of $\mathrm{NaCl}$ crystals to normal isotonic growth medium to obtain a final osmolarity of $500 \mathrm{mOsm}$, as confirmed by direct measurement in an osmometer. When the cells reached confluent density in isotonic medium, some were switched to hypertonic $500 \mathrm{mOsm}$ medium and allowed to equilibrate for $24 \mathrm{~h}$ prior to drug addition. Treatment with drugs was for $24 \mathrm{~h}$ in either isotonic or hypertonic growth medium. Osmolyte transport was assessed in the absence of drugs but immediately after the drug treatment pe- 
riod. Betaine/GABA transport (BGT1) activity was determined by measuring the initial rate (10 min uptakes) of $\mathrm{Na}^{+}-$ dependent accumulation of $\left[{ }^{3} \mathrm{H}\right] \mathrm{GABA}$ by cell monolayers, as in our previous studies $[19,20]$. The osmolarity of all solutions used in the transport assays was matched to the previous growth medium by sucrose addition, as in earlier studies $[19,20]$. Similarly, using 10 min uptakes, $\left[{ }^{3} \mathrm{H}\right]$ taurine was used as substrate for the $\mathrm{Na}^{+} /$taurine cotransporter [21], and $\left[{ }^{14} \mathrm{C}\right]$ methylaminoisobutyric acid (MeAIB) was used as substrate for the $\mathrm{Na}^{+}$-dependent system A transporter [22]. Cells maintained in isotonic medium served as controls.

Preparation of whole cell lysates, gel electrophoresis and western blotting procedures were described in our previous studies $[19,20]$. The blots were probed with a mixture of antibodies (1:1000 dilution) to both full-length and cleaved caspase 3 (Cell Signaling Technology, Beverly, MA), which were a kind gift from Dr Fred Pavalko in this department. Aspirin (salicylic acid), acetaminophen and caffeine were obtained from Sigma (St Louis, MO), and NS-398 was from Cayman Chemical (Ann Arbor, MI). Stock solutions were prepared in DMSO, ethanol or phosphate buffered saline, as appropriate, at 1000-fold working concentrations.

Data are presented as mean \pm SD from 3-6 separate experiments. In each experiment the mean value was derived from triplicate determinations. Significant differences between groups were evaluated by ANOVA and Tukey's test for multiple comparisons, using Instat v.3.06 software (GraphPad). A probability of $\mathrm{p}<0.05$ was considered statistically significant.

\section{RESULTS AND DISCUSSION}

As expected, MDCK cells previously adapted to hypertonic $(500 \mathrm{mOsm})$ growth medium for $24 \mathrm{~h}$ showed a more than10-fold upregulation of BGT1 transport activity compared to isotonic controls (Fig. (1), aspirin absent). In this initial study the addition of aspirin (range $0.1-1.0 \mathrm{mM}$ ) to the hypertonic medium for a further $24 \mathrm{~h}$ produced dosedependent inhibition of BGT1 transport (Fig. 1). Inhibition was detected at 0.1 and $0.3 \mathrm{mM}$ and appeared to be maximal at $1.0 \mathrm{mM}$ because higher doses of 3.0 and $10.0 \mathrm{mM}$ did not increase the degree of inhibition significantly (not shown). The inhibitory action at $1.0 \mathrm{mM}$ compares well with the serum level of aspirin (1-2 $\mathrm{mM}$ ) that is effective in treating rheumatoid arthritis [8]. Aspirin action on BGT1 transport in isotonic controls was not dose-dependent, although the percent inhibition at $1.0 \mathrm{mM}$ was similar to that in hypertonic cells (Fig. 1). The therapeutic level of acetaminophen is about $0.1 \mathrm{mM}$ and toxicity occurs when excessive consumption leads to serum levels that exceed $2.0 \mathrm{mM}$ [8]. The plasma caffeine level after normal coffee consumption (1-2 cups) remains less than $0.1 \mathrm{mM} \mathrm{[23]} \mathrm{and} \mathrm{may} \mathrm{be} \mathrm{fatal} \mathrm{in} \mathrm{the}$ range $0.5-2.0 \mathrm{mM}$ [8]. Higher levels of these drugs may occur locally in the renal medulla when water conservation is maximal. Based on these initial data and information, the standard protocol for comparing the different drugs was a 24 $\mathrm{hr}$ exposure to a concentration of $1.0 \mathrm{mM}$, using cells previously adapted to hypertonic stress $(500 \mathrm{mOsm})$ for $24 \mathrm{hr}$.

Two different medullary cell lines were compared in parallel in order to focus on consistent effects of drug treatment and to avoid cell-specific responses. Control $\mathrm{IMCD}_{3}$ cells in

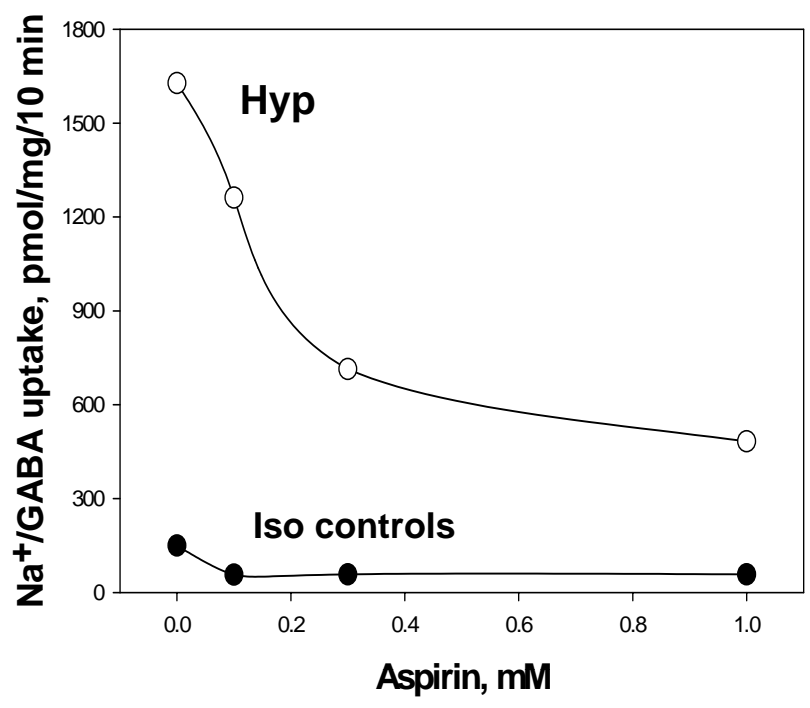

Fig. (1). Dose dependent inhibition of BGT1 transport activity by aspirin after hypertonic upregulation. Cell monolayers were incubated for $24 \mathrm{~h}$ in either hypertonic (Hyp, $500 \mathrm{mOsm}$ ) or normal isotonic (Iso) growth medium, followed by a further $24 \mathrm{~h}$ at the same osmolarity and in the presence or absence of aspirin. BGT1 transport was then determined as $\mathrm{Na}^{+}$-dependent uptake of $\left[{ }^{3} \mathrm{H}\right] \mathrm{GABA}$, after a $10 \mathrm{~min}$ incubation, and corrected for cell protein. Data are mean of two experiments, each analyzed in triplicate.

normal isotonic growth medium showed no response to drugs. In contrast, $\mathrm{IMCD}_{3}$ cells adapted to hypertonic medium showed significant inhibition of BGT1 after 24hr exposure to aspirin, acetaminophen and caffeine at $1.0 \mathrm{mM}$ (Fig. (2), upper panel). The response of MDCK cells was similar, namely all drugs inhibited BGT1 transport after hypertonic adaptation but there was no significant change in the isotonic controls (Fig. (2), lower panel).

Transport of taurine, another osmolyte, also was inhibited by aspirin and acetaminophen in $\mathrm{IMCD}_{3}$ cells following hypertonic stress (Fig. 3). NS-398, a specific inhibitor of COX2 $[2,5,8]$ reproduced the inhibitory action of aspirin on taurine transport (Fig. 3) and BGT1 (not shown), suggesting that prostaglandins may be important for maintaining upregulation of osmolyte transport during hypertonic stress. NS-398 was used at $0.01 \mathrm{mM}$ final concentration which does not affect COX1 and was previously shown to inhibit $\mathrm{PGE}_{2}$ production in $\mathrm{IMCD}_{3}$ cells [8]. As with BGT1 transport (Fig. 2) the drugs had no effect under isotonic conditions (Fig. 3), suggesting that hypertonicity may sensitize the cells to drug action on these transport systems.

In contrast to osmolyte transporters, the system A transporter for amino acids showed no significant response to NS398, aspirin and acetaminophen in both $\mathrm{IMCD}_{3}$ and MDCK cells (Fig. 4). This indicates that inhibition of BGT1 and taurine transport by these drugs was not simply a nonspecific effect due to disruption of the transmembrane sodium gradient, which is the driving force for these transport systems.

Hypertonic stress alone or in combination with aspirin treatment did not activate caspase 3 in $\mathrm{IMCD}_{3}$ and MDCK cells. Western blotting of whole cell lysates detected only the 


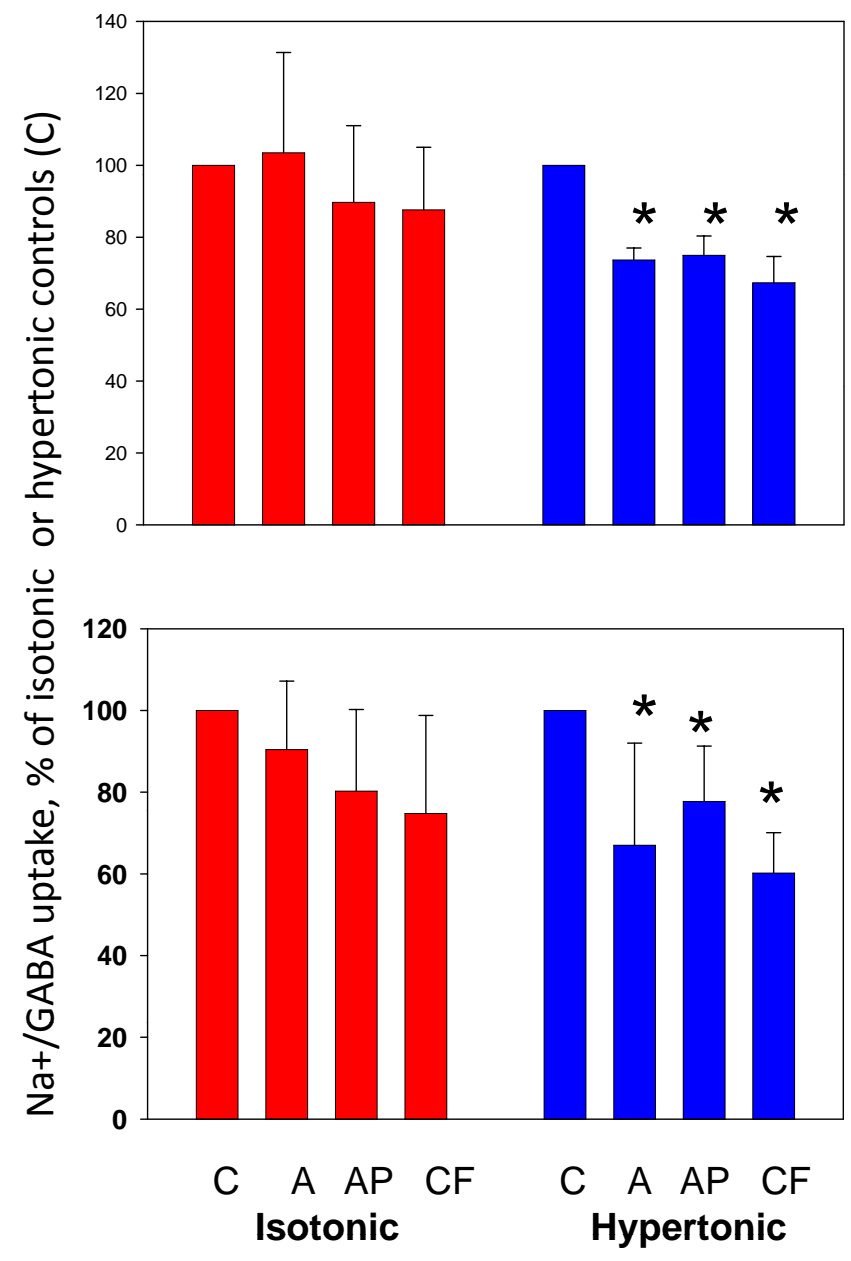

Fig. (2). Inhibition of BGT1 transport in $\mathrm{IMCD}_{3}$ and MDCK cell monolayers by aspirin, acetaminophen and caffeine at 1.0 mM. All treatments produced significant inhibition of BGT1 transport in $\mathrm{IMCD}_{3}$ (upper panel) and MDCK (lower panel) cells adapted to hypertonic medium but isotonic controls were not altered significantly. *Significantly different $(\mathrm{p}<0.05)$ from appropriate untreated controls $(\mathrm{C})$. Data are mean $\pm \mathrm{SD}$ from $3\left(\mathrm{IMCD}_{3}\right)$ or $5-6$ (MDCK) experiments. Absolute values for BGT1 transport in C groups of $\mathrm{IMCD}_{3}$ were $59 \pm 13$ (isotonic) and $161 \pm 30$ (hypertonic) $\mathrm{pmol} / \mathrm{mg} / 10 \mathrm{~min}$, and values for C groups of MDCK were $198 \pm 35$ (isotonic) and $1356 \pm 336$ (hypertonic) pmol/mg/10 min. A, aspirin; $\mathrm{AP}$, acetaminophen; $\mathrm{CF}$, caffeine.

full-length inactive caspase 3 at $35 \mathrm{kDa}$ (Fig. 5A), indicating that apoptosis was not induced. Lysate samples from osteoblastic cells were used as controls to validate the western technique. The activated $17 \mathrm{kDa}$ fragment of caspase 3 was detected in lysates from cells made apoptotic by addition of tumor necrosis factor- $\alpha$ and cycloheximide, as expected from previous reports $[24,25]$, but was absent from untreated controls (Fig. 5B). In addition, the drug-treated kidney cells showed no evidence of rounding or detachment. Taken together, these findings indicate that inhibition of BGT1 and taurine transporters by $1.0 \mathrm{mM}$ aspirin treatment for $24 \mathrm{~h}$ was not an indirect result of apoptotic events. Aspirin at higher concentrations and longer exposure was shown previously to induce DNA damage and apoptosis, especially in rapidly proliferating $\mathrm{IMCD}_{3}$ cells $[8,9]$.
Inhibition of Taurine Uptake in IMCD3 Cells

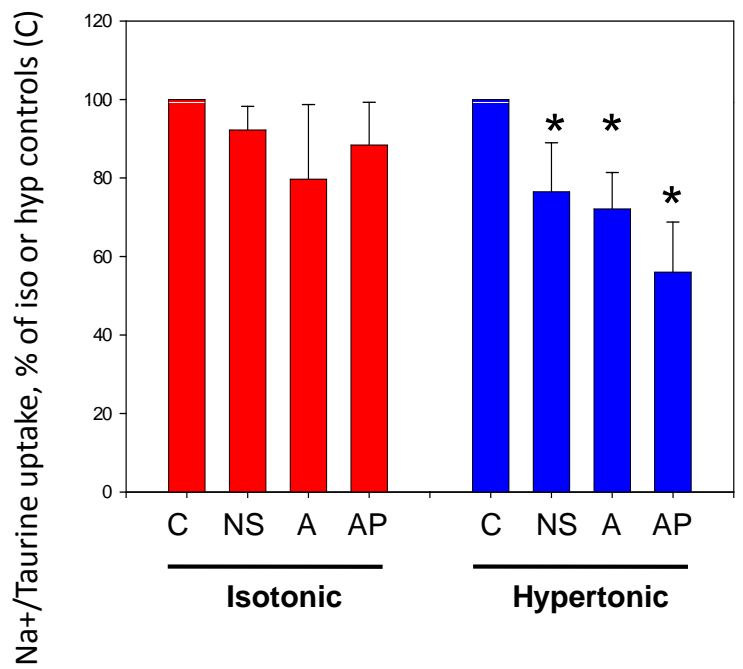

Fig. (3). Inhibition of taurine transport in $\mathrm{IMCD}_{3}$ cells by a COX2 inhibitor, aspirin and acetaminophen. All treatments inhibited taurine uptake in cells adapted to hypertonic stress, but there was no effect on isotonic control cells. *Significantly different $(\mathrm{p}<0.05, \mathrm{n}=4)$ compared to untreated group C. Absolute values for taurine transport in group C were $672 \pm 223$ (isotonic) and $1340 \pm 240$ (hypertonic) pmol/mg/10 min. NS (NS-398) was present at $0.01 \mathrm{mM}$, and $\mathrm{A}$ and $\mathrm{AP}$ were $1.0 \mathrm{mM}$.

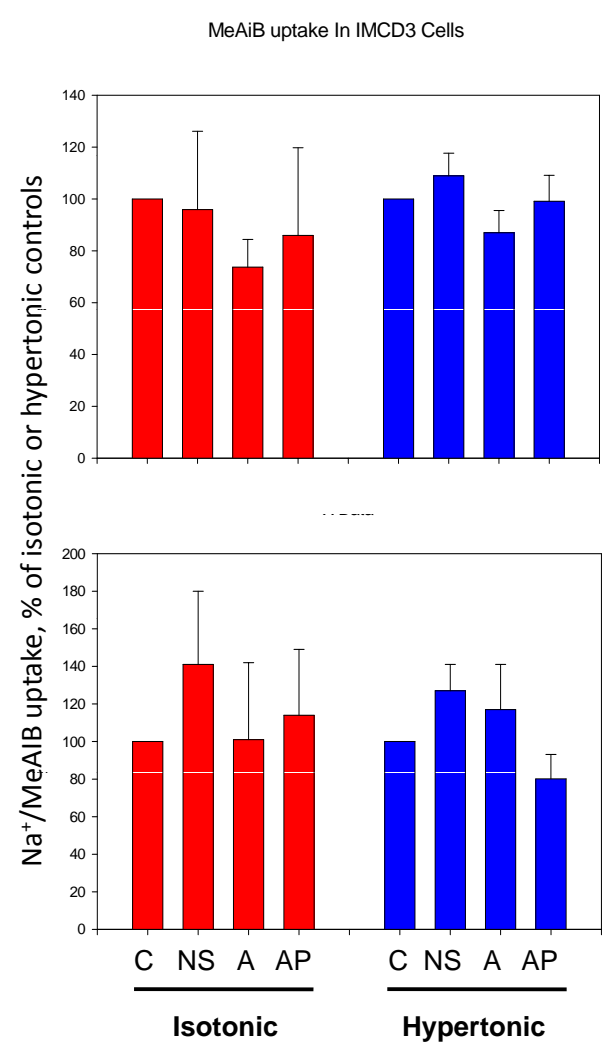

Fig. (4). The system A amino acid transporter was not inhibited by NS-398, aspirin or acetaminophen. System A transport in $\mathrm{IMCD}_{3}$ (upper) and MDCK (lower) cells was determined as $\mathrm{Na}^{+}-$ dependent uptake of $\left[{ }^{14} \mathrm{C}\right] \mathrm{MeAIB}$, and was not altered by drug treatment. See Fig. (3) for other details. 

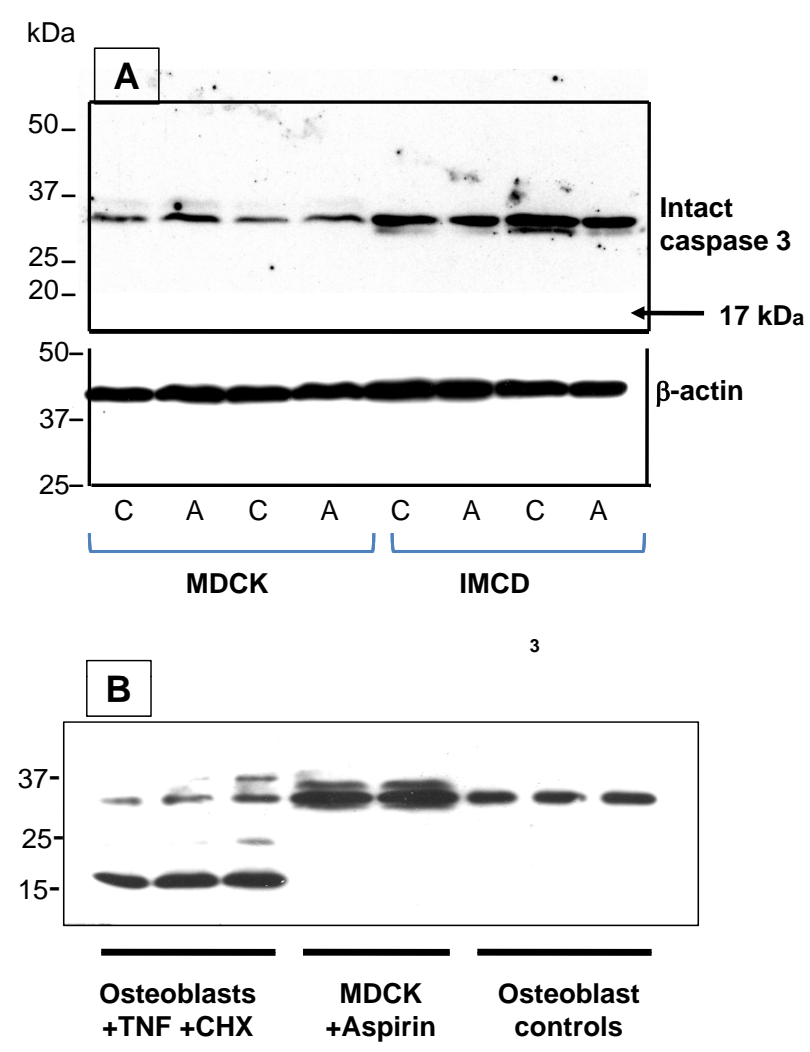

Fig. (5). Aspirin did not activate caspase 3 in either MDCK or $\mathbf{I M C D}_{\mathbf{3}}$ cells. (A) Western blotting of whole cell lysates detected only full-length inactive caspase $3(35 \mathrm{kDa})$. No activated cleaved fragments were present. Blots were probed with a mixture of antibodies to both intact and cleaved caspase 3 . All cells were adapted to hypertonic growth medium for $24 \mathrm{~h}$ prior to a further $24 \mathrm{~h}$ incubation in the presence (A) or absence (C) of $1.0 \mathrm{mM}$ aspirin. (B) Lysates from mouse osteoblastic (MC3T3-E1) cells were used as controls. When these cells were made apoptotic by $4 \mathrm{~h}$ exposure to tumor necrosis factor- $\alpha$ (TNF, $5 \mathrm{ng} / \mathrm{ml})$ ) and cycloheximide (CHX, $10 \mathrm{ng} / \mathrm{ml}$ ), a $17 \mathrm{kDa}$ fragment of activated caspase 3 was detected, as expected from a previous study [25]. No activated fragments were detected in untreated controls or in aspirin-treated MDCK cells.

This report of consistent findings in two different lines of renal medullary cells is the first description of impairment of renal osmolyte transport by NSAIDs and analgesics. The potential mechanisms have not been determined although non-specific toxicity and apoptosis can be ruled out. Overthe-counter aspirin is sold as acetylsalicylic acid which is rapidly converted to salicylic acid after ingestion [8], and is the form tested here in vitro. The action of aspirin was reproduced by a COX2 specific inhibitor, suggesting that aspirin may act via inhibition of COX2 and possible depletion of prostaglandins important for maintaining the adaptation to hypertonic stress. Further studies are needed to confirm this. Caffeine inhibition of osmolyte transport may be related to its action to mobilize intracellular stores of $\mathrm{Ca}^{2+}$ in many cells including MDCK $[26,27]$. We have previously shown that an increase in intracellular $\mathrm{Ca}^{2+}$ is associated with prompt endocytic retrieval of BGT1 protein from the plasma membrane [20]. The mechanism of acetaminophen inhibition remains to be determined but it is possible to speculate based on studies of acetaminophen action in the liver. These have led to the proposal that the metabolites of acetaminophen may eventually deplete intracellular glutathione which will be followed by onset of oxidative stress [9, 28]. A similar response in cells of the renal medulla would be very significant because we have previously observed a direct inhibitory action of oxidative stress on specific plasma membrane transport systems in cultured kidney cells [29].

In summary, interference with the ability of medullary cells to accumulate osmolytes may contribute to certain nephrotoxic effects in vivo, such as papillary necrosis [30], that result from long-term use of NSAIDs and analgesic mixtures containing acetaminophen and caffeine. The hypertonic environment in the inner medulla in vivo also may sensitize the cells to the action of these drugs. Additional toxic effects, as reported elsewhere, may occur in vivo due to concentration of these drugs in the renal inner medulla during antidiuresis.

$\begin{array}{ll}\text { ABBREVIATIONS } & \text { Betaine/GABA transporter } \\ \text { BGT1 } 1= & \text { Cyclooxygenase } \\ \text { COX }= & \text { Non-steroidal anti-inflammatory drug } \\ \text { NSAID }= & \gamma \text {-aminobutyric acid } \\ \text { GABA }= & \text { Madin-Darby canine kidney } \\ \text { MDCK }= & \text { Inner medullary collecting duct. }\end{array}$

\section{ACKNOWLEDGEMENTS}

Supported by the National Kidney Foundation of Indiana (SAK), and an IUPUI Life-Health Sciences Internship (BMA). JB was a participant in Indianapolis Project SEED sponsored by the American Chemical Society.

\section{REFERENCES}

[1] Brater DC, Harris C, Redfern JS, Gertz BJ. Renal effects of COX-2 selective inhibitors. Am J Nephrol 2001; 21: 1-15.

[2] Yang T, Huang Y, Heasley LE, Berl T, Schnermann JB, Briggs JP. MAPK mediation of hypertonicity-stimulated cyclooxygenase-2 expression in renal medullary collecting duct cells. J Biol Chem 2000; 275: 23281-6.

[3] Hao C-M, Breyer MD. Physiological regulation of prostaglandins in the kidney. Annu Rev Physiol 2008; 70: 357-77.

[4] Harris RC. COX-2 and the Kidney. J Cardiovasc Pharmacol 2006; 47: S37-S42.

[5] Ye W, Zhang H, Hillas E, et al. Expression and function of COX isoforms in renal medulla: evidence for regulation of salt sensitivity and blood pressure. Am J Physiol Renal Physiol 2006; 290: F5429.

[6] Cohen-Luria R, Moran A, Rimon G. Cyclooxygenase inhibitors suppress inhibitory effect of PGE2 on Na-K-ATPase in MDCK cells. Am J Physiol Renal Physiol 1994; 267: F94-8.

[7] Coyne DW, Mordhorst M, Morrison AR. Regulation of eicosanoid biosynthesis by phorbol ester in Madin Darby canine kidney cells. Am J Physiol Renal Physiol 1990; 259: F698-703.

[8] Rocha GM, Michea LF, Peters EM, et al. Direct toxicity of nonsteroidal antiinflammatory drugs for renal medullary cells. Proc Natl Acad Sci USA 2001; 98: 5317-22.

[9] Cai Q, Dmitrieva NI, Michea LF, Rocha G, Ferguson D, Burg MB. Toxicity of acetaminophen, salicylic acid, and caffeine for firstpassage rat renal inner medullary collecting duct cells. J Pharm Exp Ther 2003; 306: 35-42.

[10] Burg MB. Molecular basis of osmotic regulation. Am J Physiol Renal Physiol 1995; 268: F983-F96.

[11] Burg MB, Ferraris JD. Intracellular organic osmolytes: function and regulation. J Biol Chem 2008; 283: 7309-13. 
[12] Lopez-Rodriguez C, Antos CL, Shelton JM, et al. Loss of NFAT5 results in renal atrophy and lack of tonicity-responsive gene expression. Proc Natl Acad Sci USA 2004; 101: 2392-7.

[13] Aramburu J, Drews-Elger K, Estrada-Gelonch A, et al. Regulation of the hypertonic stress response and other cellular functions by the Rel-like transcription factor NFAT5. Biochem Pharmacol 2006; 72: 1597-604.

[14] Bach PH, Berndt WO, Delzell E, et al. A safety assessment of fixed combinations of acetaminophen and acetylsalicylic acid, coformulated with caffeine. Renal Failure 1998; 20: 749-62.

[15] Fored CM, Ejerblad E, Lindblad P, et al. Acetaminophen, aspirin, and chronic renal failure. N Engl J Med 2001; 345: 1801-8.

[16] Handler JS. Use of cultured epithelia to study transport and its regulation. J Exp Biol 1983; 106: 55-69.

[17] Handler JS, Perkins FM, Johnson JP. Studies of renal cell function using cell culture techniques. Am J Physiol Renal Physiol 1980; 238: F1-9.

[18] Rauchman MI, Nigam SK, Delpire E, Gullans SR. An osmotically tolerant inner medullary collecting duct cell line from an SV40 transgenic mouse. Am J Physiol Renal Physiol 1993; 265: F416-24.

[19] Kempson SA, Edwards JM, Osborn M, Sturek M. Acute inhibition of the betaine transporter by ATP and adenosine in renal MDCK cells. Am J Physiol Cell Physiol 2008; 295: F108-F17.

[20] Kempson SA, Edwards JM, Sturek M. Inhibition of the renal betaine transporter by calcium ions. Am J Physiol Renal Physiol 2006; 291: F305-F13.

[21] Jones DP, Miller LA, Chesney RW. The relative roles of external taurine concentration and medium osmolality in the regulation of taurine transport in LLC-PK1 and MDCK cells. Pediatr Res 1995; 37: $227-32$.
Kempson SA. Differential activation of system A and betaine/GABA transport in MDCK cell membranes by hypertonic stress. Biochim Biophys Acta 1998; 1372: 117-23.

[23] Chelsky LB, Cutler JE, Griffith K, Kron J, McClelland JH, McAnulty JH. Caffeine and ventricular arrhythmias. An electrophysiological approach. JAMA 1990; 264: 2236-40.

[24] Calvo NG, Gentili CR, Russo de Boland A. The early phase of programmed cell death in Caco-2 intestinal cells exposed to PTH. J Cell Biochem 2008; 105: 989-97.

[25] Pavalko FM, Gerard RL, Ponik SM, Gallagher PJ, Jin Y, Norvell SM. Fluid shear stress inhibits TNF-alpha-induced apoptosis in osteoblasts: A role for fluid shear stress-induced activation of PI3 kinase and inhibition of caspase-3. J Cell Physiol 2003; 194: 194205.

[26] Kim DK, Jung KY. Caffeine causes glycerophosphorylcholine accumulation through ryanodine-inhibitable increase of cellular calcium and activation of phospholipase A2 in cultured MDCK cells. Exp Mol Med 1998; 30: 151-8.

[27] Kong H, Jones PP, Koop A, Zhang L, Duff HJ, Chen SR. Caffeine induces $\mathrm{Ca}^{2+}$ release by reducing the threshold for luminal $\mathrm{Ca}^{2+} \mathrm{ac}-$ tivation of the ryanodine receptor. Biochem J 2008; 414: 441-52.

[28] Kaplowitz N, Shinohara M, Liu Z, Han D. How to protect against acetaminophen: don't ask for JUNK. Gastroenterology 2008; 135 1047-51

[29] Andreoli SP, McAteer JA, Seifert SA, Kempson SA. Oxidantinduced alterations in glucose and phosphate transport in LLC-PK1 cells: mechanisms of injury. Am J Physiol Renal Physiol 1993; 265: F377-84

[30] Porter GA. Acetaminophen/aspirin mixtures: experimental data Am J Kidney Dis 1996; 28: S30-S33.

(C) Bonner et al.; Licensee Bentham Open.

This is an open access article licensed under the terms of the Creative Commons Attribution Non-Commercial License (http://creativecommons.org/licenses/bync/3.0/) which permits unrestricted, non-commercial use, distribution and reproduction in any medium, provided the work is properly cited. 